\title{
Hong Kong 1995
}

\author{
By Limin Teh and Toh Hai Leong
}

Fall 1995 Issue of KINEMA

SINCE 1985 THE HONG KONG INTERNATIONAL FILM FESTIVAL (HKIFF) has been the guardian of Asian cinema. Apart from screening an eclectic range of Asian and international films, it regularly runs comprehensive retrospectives which highlight both prominent and little-known Asian directors in events such as the thematic "Hong Kong Cinema Retrospective."

In celebrating the Centenary of Cinema this year, the 19th HKIFF focused its attention on archival motion pictures collectively titled "Early Images of Hong Kong and China." An exhibition of the same theme was held concurrently at the City Hall.

Among the most striking of the nearly 126 films from 44 countries exhibited in the Colony's bustling art cinemas were engaging movies that featured peculiar familial clans, haunted loners and bizarre relationships.

The intensive 16-day affair (7th to 22nd April) opened with Jiang Wen's rites-of-passage film, In the Heat of the Sun. In his introductory speech, the acclaimed Mainland Chinese actor-turned-director (he was the leading actor in Red Sorghum) proclaimed his loyalty to his "new-found mistress, the cinema, which he cannot afford to abandon now that he has turned filmmaker" with self-detractory charm. It was a shock to discover that his debut had been banned in both his homeland and in Taiwan.

Brilliantly directed, Jiang's bold tracking camera and nostalgic voice-over create cinematic magic as he fondly recollects the wild days of his Beijing youth during the Cultural Revolution. The film certainly is far from the dictates of a "socialist film" in its refreshing story of five miscreants who spend their days playing pranks, gangland fighting, skirt-chasing and mayhem-making. As a new type of Mainland film, Heat is hard to categorise as it does not contain either the Fifth Generation's cultural angst nor the Sixth Generation's proclivity for self-probing. Produced by a leftist Hong Kong individual, the film is a symbolic gesture of creative freedom and political incorrectness in an age of conformity and repression.

The most prominent feature of Heat is the absence of families in the film with the exception of the young protagonist, Monkey. This fact speaks volumes about the delinquency of the boys concerned.

There were, however, many other film families to be found at this year's festival: these were from Ireland (the plotless and obviously titled Family), New Zealand (Peter Jackson's Heavenly Creatures; Lee Tamahori's Maori film Once Were Warriors), Australia (P.J. Hogan's Muriel's Wedding), Hong Kong (Yim Ho's The Day The Sun Turned Cold), Stalinist Russia (Nikita Mikhalkov's Burnt By the Sun, and the United States (Crumb by Terry Zwigoff, a documentary about the underground cartoonist Robert Crumb and his two intoxicated siblings).

Varied and international, these families share one trait in common: eccentricity - sometimes to the audience's delight, at other times to their horror and incomprehension, as was the case in Crumb which saw many leaving before the film had reached its first half. The violent family film Once Were Warriors returned to the past which had shaped the proud and warlike nature of the Maoris. The male figure is portrayed quite unsympathetically as a macho wife-abuser who uses his slave status as an excuse to indulge in sex and alcohol through self-pity.

Heavenly Creatures is about two girls who become inseparable and subsequently commit murder. Yim Ho's masterpiece, The Day the Sun Turned Cold deals with the strange love-hate relationship between a son (the adult is played by Taiwan's heartthrob Tuo Chong Hwa) and his mother (played by Swiss-Mongolian actress, Siqin Gaowa).

Both films showed flashes of commercial appeal as they were fully attended by a more discriminating audience. In fact, Yim Ho's film had already been shown commercially in an up-market art cinema house and the story of the two young murderesses would later get a general release with good box-office returns.

Other films in the festival also had their share of pessimism and murder. The interesting remake by Hungarian János Szasz has at its centre a brooding Woyzeck who is assailed by loneliness and humiliated by his wife's 
adultery. Eventually he dispatches her into eternity. The Peruvian Francisco J. Lombardi recreated No Mercy based on the Dostoyevskyian tale of crime, redemption and punishment. Ramon, a tormented law student, kills his landlady with a vehemence exacerbated by his poverty and hatred of "greedy capitalists." Unable to cope with his vicious crime, his guilt weighs on him like the proverbial albatross.

The Russian version on the same theme, Whispering Pages, by Aleksandr Sokurov is wretchedly monotonous consisting mostly of silent scenes showing the guilt-ridden hero moving through the dark like a zombie.

The Quality of Mercy by the German director Andreas Gruber is a powerful work which easily outranks Spielberg's overrated Schindler's List. The former is based on the true story of 500 Soviet soldiers who break out of a concentration camp - but only a handful escape alive. The film shows the brutality of the so-called Mühlviertler Rabbit Hunt in which the Red soldiers are mercilessly hunted down by the local militia and SS storm troopers. The authenticity of the killings leave audiences cringing.

Probably the most controversial film at the festival which many heterosexual viewers found fascinating was Priest, an English film about the travails of a gay priest, directed by Antonia Bird and written by Jimmy McGovern. Young, handsome and idealistic cleric (Linus Roache) is full of enthusiasm for his Catholic calling. However his sexual orientation puts him at odds with his vocation. Later when he discovers that a young girl is forced by her natural father to commit incest and he is unable to reveal this due to the confidentiality of confession, he suffers a deep spiritual crisis in which his whole notion of faith, God and love is questioned.

Regardless of the position one may take in this controversial film, it is safe to say that few English films, if any, have ever ventured into such taboo territory.

The most popular of the "sub-festivals" at the HKIFF is still the important Asian Film section. There is no denying that the Koreans are important filmmakers to be reckoned with; Veteran Im Kwon-taek's Taebaek Mountains and his younger compatriot Park Kwang-su's To the Starry Island are introspective films which delve into the past to examine the deep division that still separates the North and the South (represented by the regretful past and the uneasy present). The arrangement of screening these two films back-to-back allowed for comparison and gave the opportunity to students of Korean cinema to contrast the differing style of the two auteurs. Im follows a more philosophical approach in his conflicting tale of two brothers who clash over political ideologies.

Park seems to be more concerned with the metaphysical; his work shows the unmistakable influence of Ingmar Bergman. For example, in his film, the dance of the dead in the sky parallels the famous Dance of Death in Seventh Seal. It is clear from the emergence of Im Kwon-taek's Sopyonjie last year that Korean cinema has reached a new maturity which more than rivals the higher profile of Hong Kong. Taiwanese and Mainland Chinese cinemas.

On the Hong Kong film scene, maverick director Wong Kar-wai stole the limelight from his colleagues with two of his landmark works being screened side by side - the laboured Ashes of Time and Chungking Express. Though the latter was said to have been done by Wong because he wanted a break from working on Ashes, the contemporary tale (consisting of two separate stories) on lost love and urban anomie is the better and more coherent film. Stanley Kwan's Red Rose White Rose is unfortunately overwhelmed by its fluffy prettiness.

After Rouge (1988), Kwan has not been making noteworthy films except for the "masterful" slickness and vacant beauty that distinguish Full Moon in New York (1989) and Centre Stage (1991) (aka Main Actress or Ruan Lingyu). Winston Chao, the amour in Red Rose White Rose who is besotted by two contrasting beauties - one passionately red-hot, the other icily frigid (played comatosely by Joan Chen and Veronica Yip respectively), looks confused and lost in the bungled trysts he sets upon himself. One wonders why Chris Doyle, the acclaimed cinematographer, really went to all the trouble to shoot it. Peter Chan, the "Billy Wilder of the East," fared better. His He's a Man, She's a Woman is a spontaneously funny film which pokes fun at the narrow-mindedness of Hongkongers on gender and cross-sexuality issues. The audience was left practically rolling on the floor.

For the first time in the festival's history, a short $(16 \mathrm{~mm})$ film from Singapore was premiered - Eric Khoo's Pain (1994). This disputed film is banned in Singapore for depicting acts of excessive violence. The film gives an extremely unrealistic portrayal of senseless violence and self-inflicted pain on the part of a psychopathic 
protagonist who not only gets away with committing a heinous crime but who later becomes a policeman. The overall bad acting is barely "salvaged" by Khoo's use of heavy silence. Not even the high praise received from some "international" critics can raise Pain to the level of art or respectability. At its screening in Hong Kong, the film was perceived as more of a comedy than an insight into the workings of a psychotic mind.

A more credible and authentic portrait of a psychotic is presented by the American director Lodge Kerrigan in Clean, Shaven. The film is about a schizophrenic going through an emotional crisis. The unearthly and disembodied dialogue signifies the fractured, tortured soul-voice of a (suspected) child-murderer. This minimalist film discards the flashy trappings of Hollywood's serial-killer film genre and is the more effective for it.

Still on the same topic, the debut (video) work by Taiwanese Ivan Chen screened after Pain fared far better in handling this obsession than Eric Khoo and without resorting to graphic portrayal. The youthful audience who went to see both works really must have wondered at the senselessness depicted by Khoo which obscured the plot's tangibility. One can only infer this is not his original intention.

The HKIFF is about the only festival where one can find John Ford's archival Straight Shooting (1917) and Bu Wanchang's 1931 Love and Duty (starring the legendary Shanghainese waif Ruan Lingyu) in the same programme book. The organisers must be complimented for their effort in bringing back the joy of watching the silent classics with live music accompaniment. The raw energy of John Ford is far better captured with the use of a live band (the local band Ha! deserves the accolades) than that of a string orchestra. It also gives the restored work a more modern feel. In spite of the hype over Stanley Kwan's over-stylized Centre Stage about the life of the Chinese silent screen actress Ruan Lingyu, there are few of us who have the luxury or good fortune to see an original Ruan film. In Love and Duty, Ruan plays the role of a tragic heroine who is trapped by life's misfortunes. In real life, Ruan committed suicide at the age of twenty-five. A decade or so later, the singer-actress Zhou Xuan, who starred in the semi-autobiographic 1948 melodrama, Song of a Songstress, suffered the same fate.

At a time when many movie-goers have forgotten that mere novelty is no proof of value, classics like these confirm filmmaking as an art form.

As the festival drew to a close, the future of the HKIFF was inevitably on the minds of all those who had become regular visitors to this annual event. After the return of the British Colony to Mainland China on 1st July 1997, will the achievements of world cinema still be celebrated in Hong Kong? Will Hong Kong cinema, now more than 60 years old, be allowed to flourish? Or is this the "last flicker of the candle" which for more than a decade has been putting the spotlight on Asian Cinema? When the Guardian film critic Derek Malcolm compared the Singapore International Film Festival (1995 is its 8th year) to that of the more established 19th HKIFF, he saw more potential for development on the Singapore side, citing 1997 as the main reason. What will happen to the HKIFF and to Hong Kong cinema after 1997 is anybody's guess. Those who have come to appreciate the HKIFF can only keep their fingers crossed and hope for the best. 